\title{
Characterization of Cell Cycle Events in Synchronized Cultures of Anacystis nidulans
}

\author{
By YUKIO ASATO \\ Department of Biology. Southeastern Massachusetts University. North Dartmouth. \\ Massachusetts 02747, USA
}

(Received 20 February 1984 ; recised 31 May 1984)

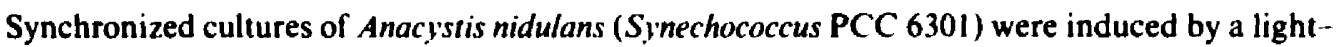
dark incubation scheme under moderate light intensity $\left(3.2 \mathrm{~J} \mathrm{~m}^{-2} \mathrm{~s}^{-1}\right)$. At incubation temperatures of $32^{\circ} \mathrm{C} .35^{\circ} \mathrm{C}$ and $38^{\circ} \mathrm{C}$, typical step-wise growth cycles were observed at growth rates of 8,6 and $4 \mathrm{~h}$ doubling times, respectively. Using the same method of inducing cell synchrony but under increased light intensity $\left(4.8 \mathrm{~J} \mathrm{~m}^{-2} \mathrm{~s}^{-1}\right)$, cell number increased exponentially and growth rates were twice as high as those at the lower light intensity, at incubation temperatures of $32^{\circ} \mathrm{C}, 35^{\circ} \mathrm{C}$ and $38^{\circ} \mathrm{C}$. At $32^{\circ} \mathrm{C}$ under high light intensity, the synthesis of protein, RNA, DNA and cell wall material occurred periodically in a temporal order, although cell number increased exponentially. The data suggested that the growth of Anacystis under these conditions could essentially be characterized as synchronized. The macromolecular synthesis periods (cell cycle events) are apparently controlled by complex sets of genetic and metabolic controls that allow Anacystis to take advantage of changing environmental conditions.
\end{abstract}

\section{INTRODUCTION}

There are several interesting growth characteristics of the obligate photoautotroph Anacystis nidulans (Sy'nechococcus PCC 6301) that have yet to be demonstrated in other obligate photoautotrophs. For example, bulk protein, RNA, DNA and phospholipid synthesis occurs at specific times in the cell division cycle. There is a temporal order of the macromolecular synthesis periods in synchronized cultures of Anacystis (Asato, 1979). Dark incubation causes the cell cycles to be aborted and a new cell cycle is initiated when the culture is re-exposed to the light (Asato, 1983). These results suggest that there must be a co-ordination of complex sets of mechanisms that control the macromolecular synthesis periods (cell cycle events) in Anacystis. In heterotrophic organisms growth rates can be increased by increasing the incubation temperature or by enriching the growth medium with various nutrients. In an obligate photoautotroph such as Anacystis, growth rates can be increased by increasing the temperature of incubation or the light intensity (Mann \& Carr, 1974). In this communication the effects of high light intensity on the synchronized culture of Anacystis are reported. The results of this study demonstrate unusual growth patterns of Anacystis in response to high light intensity. Although this study was not intended to investigate the detailed mechanisms of the control of the cell cycle, the data support the proposal that complex regulatory mechanisms are co-ordinated in controlling the cycle events of Anacystis (Asato, 1983).

\section{METHODS}

The organism, Anacystis nidulans (Synechococcus PCC 630I), growth conditions, and the method of inducing synchronized growth have been described elsewhere (Asato, 1979, 1983) as have the pulse-labelling and measurements of protein, RNA and DNA fractions. Percentage errors calculated by standard deviation for protein, RNA and DNA measurements were $8^{\circ}{ }_{0}, 10^{\circ}{ }_{0}$ and $12^{\circ}{ }_{0}$, respectively. Moderate and high light intensities 
refer to $3.2 \mathrm{~J} \mathrm{~m}^{-2} \mathrm{~s}^{-1}$ and $4.8 \mathrm{~J} \mathrm{~m}^{-2} \mathrm{~s}^{-1}$, respectively. Cell wall synthesis was determined as follows. N-Acetyl-D$\left[1^{-3} \mathrm{H}\right.$ glucosamine [sp. act. $2.9 \mathrm{Ci}(107.3 \mathrm{GBq}) \mathrm{mmol}^{-1}$; Amersham] was added to obtain $12.5 \mu \mathrm{Ci}$ per ml of culture for $30 \mathrm{~min}$. Labelling was stopped by adding cold TCA to a I ml sample of culture (final concentration $5^{\circ}{ }_{{ }^{\circ}}$. w/v) and the mixture was placed in an ice bath for $15 \mathrm{~min}$. The mixture was then filtered on fibre glass filters (Whatman GF/B), washed with cold $5 \%$ TCA, dried and placed in scintillation fluid (Aquasol-2, New England Nuclear). The radioactivity was measured on a Packard scintillation counter. The percentage error for cell wall synthesis was $8 \%$.

\section{RESULTS AND DISCUSSION}

\section{Growth characteristics under moderate and high light intensity}

Synchronized cultures of Anacystis, induced by a dark incubation period of about 12-24 h, demonstrated a characteristic step-wise growth pattern under moderate light intensity. At incubation temperatures of $32^{\circ} \mathrm{C}, 35^{\circ} \mathrm{C}$ and $38^{\circ} \mathrm{C}$, the doubling times were 8,6 and $4 \mathrm{~h}$, respectively (Asato, 1979) (Fig. 1). When the light intensity was increased, there were two interesting effects on the synchronized cultures. First, cell number increased exponentially instead of showing the step-wise growth pattern that was expected. Second, the growth rates doubled, i.e. the doubling times were 4,3 and $2 \mathrm{~h}$ for the growth temperatures of $32^{\circ} \mathrm{C}, 35^{\circ} \mathrm{C}$ and $38^{\circ} \mathrm{C}$, respectively (Fig. 1). To evaluate further the growth curves under high light intensity, Arrhenius plots of growth rates were determined for 'synchronized' cultures under high light intensity and exponential cultures under moderate light intensity (Fig. 2). For incubation temperatures of $32^{\circ} \mathrm{C}$ to $38^{\circ} \mathrm{C}$, the growth rate values increased exponentially when the cultures were exposed to either high or moderate light intensity, with temperature coefficients of $55.5 \mathrm{~kJ} \mathrm{~mol}^{-1}$ and $27.7 \mathrm{~kJ} \mathrm{~mol}^{-1}$, respectively. High light intensity apparently increased the rate of photosynthesis. The increased photosynthetic products facilitated and increased the biochemical reactions within the cell consequently leading to an increase in growth rate. It should be pointed out that the growth rates in the Arrhenius plots were obtained from exponential cultures continuously incubated under moderate light intensity (data not shown) whereas the growth rates under high light intensity were obtained from the curves shown in Fig. 1. In each case, the cultures grown under high light intensity (as in Fig. 1) responded to the temperature effects in the same manner as the normal exponential cultures grown under moderate light intensity.

\section{Patterns of macromolecular synthesis}

In order to understand the basis for the growth patterns at high light intensity, the rates of macromolecular synthesis were measured. In a typical study, an exponential culture (grown under high light intensity) was incubated in the dark for $16 \mathrm{~h}$ and then exposed to high light intensity. Samples of $2.5 \mathrm{ml}$ were pulsed with radioactive precursors for 30 to $60 \mathrm{~min}$. At an incubation temperature of $32^{\circ} \mathrm{C}$, the rates of protein, RNA and DNA synthesis showed a periodic pattern (Fig. 3). The pattern of macromolecular synthesis shown in Fig. 3 resembled but was not superimposable on the pattern of macromolecular synthesis found in a $4 \mathrm{~h} \mathrm{cell} \mathrm{cycle}$ reported previously (Asato, 1979) for synchronized cultures grown at $38^{\circ} \mathrm{C}$ under moderate light intensity. A major difference in the patterns of macromolecular synthesis was the occurrence of an additional peak in RNA synthesis in the dark-to-light transition period during $0-4 \mathrm{~h}$. The basis for this additional peak in RNA synthesis is not yet known. Furthermore, the RNA synthesis peaks occurred at a $3 \mathrm{~h}$ rather than a $4 \mathrm{~h}$ interval. Earlier, or in some cases later, appearances of macromolecular synthesis peaks are not unusual in synchronized cultures grown at moderate or high light intensity. The schedules of macromolecular synthesis periods are generally corrected in subsequent cell cycles. For example, in a synchronized culture growing with a $4 \mathrm{~h}$ doubling time (see Fig. 4 of Asato, 1979), two of the three DNA and RNA synthesis peaks occurred at a $3 \mathrm{~h}$ interval while the third peak occurred $4 \mathrm{~h}$ later. Other notable differences in the synthesis pattern were that the appearance of the synthesis period did not always occur precisely on schedule, the duration of the synthesis periods varied, and the peak synthesis rates did not increase significantly from one cell doubling period to another. Repeated experimental results did, in fact, show a much more dramatic increase in macromolecular synthesis rates as 


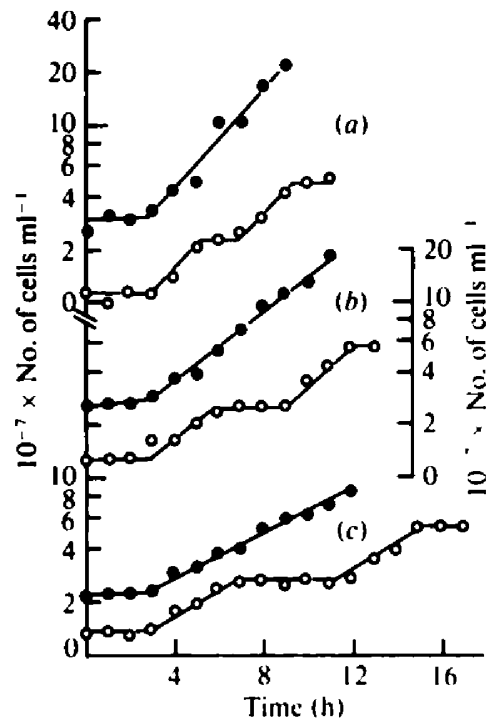

Fig. I

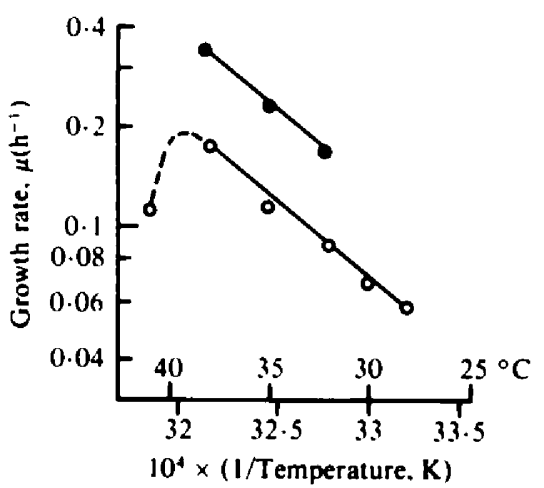

Fig. 2

Fig. 1. Growth curves of synchronized Anacystis nidulans cultures. Exponential cultures were incubated in the dark for about $16 \mathrm{~h}$ to induce cell synchrony. Cultures were then re-exposed to the light and cell counts were determined with a Petroff-Hausser cell counter. $(a)$ Cultures grown at $38{ }^{\circ} \mathrm{C}$ under moderate light intensity $\left(3.2 \mathrm{~J} \mathrm{~m}^{-2} \mathrm{~s}^{-1} ; O\right)$ and high light intensity $\left(4.8 \mathrm{~J} \mathrm{~m}^{-2} \mathrm{~s}^{-1} ; O\right)$. (b) Cultures grown at $35^{\circ} \mathrm{C}$ under moderate light intensity $(O)$ and high light intensity $(O)$. (c) Cultures grown at $32^{\circ} \mathrm{C}$ under moderate light intensity $(O)$ and at $38^{\circ} \mathrm{C}$ under high light intensity $(O)$.

Fig. 2. Arrhenius plot of growth rates of Anacystis nidulans grown under moderate and high light intensities. Growth rates under high light intensity $\left(4.8 \mathrm{~J} \mathrm{~m}^{-2} \mathrm{~s}^{-1}\right.$ : $)$ were determined from the growth curves shown in Fig. 1 . Growth rates under moderate light intensity $\left(3.2 \mathrm{~J} \mathrm{~m}^{-2} \mathrm{~s}^{-1} ; 0\right)$ were determined from exponential cultures (data not shown). Cultures were grown in Erlenmeyer flasks (medium to volume ratio of $1: 10$ ). The flasks were mixed on a rotary shaker at 200 r.p.m. Ambient $\mathrm{CO}_{2}$ served as carbon source.

well as extended synthesis periods, particularly during the initial period of growth (data not shown). For example, in a repeated experiment an unusually high initial rate of DNA synthesis was found (Fig. 3). In the ensuing cell cycles, decreased synthesis rates and synthesis periods were observed. Such variations in macromolecular synthesis rates are difficult to control experimentally since the factors that influence the synthesis rates are not known. Because of the variations in macromolecular synthesis, application of statistical analysis may not satisfactorily resolve the degree of variation in repeated experiments.

One of many possible interpretations of these results is that growth is abnormal or transitory under these conditions. On the other hand, it is possible that the cell could normally adjust the extent of macromolecular synthesis under the prevailing conditions such that extended rounds of macromolecular synthesis can occur during one cell cycle as compared to other cell cycles. As a result, the amount of macromolecules synthesized and the timing of the synthesis periods could vary from one cell cycle to the next. It turns out, however, that the question of abnormal, transitory, or normal growth may not be the central issue of concern here. An ordered pattern of macromolecular synthesis (generally found in synchronized cultures) was observed from 4-10 h consistent with a $4 \mathrm{~h}$ cell cycle. Ultimately, the genetic and metabolic control of the cell cycle events in Anacystis must be clearly defined. The observations made here could, then, be the normal expression of the cell cycle control mechanisms in response to the imposed conditions of growth.

The macromolecular synthesis periods in Anacystis may be controlled by initiators expressed in sequential order (Asato, 1983). For example, the initiation of ribosomal protein operons would, by co-ordinate regulation, lead to the transcription of an initiator of ribosomal RNA 


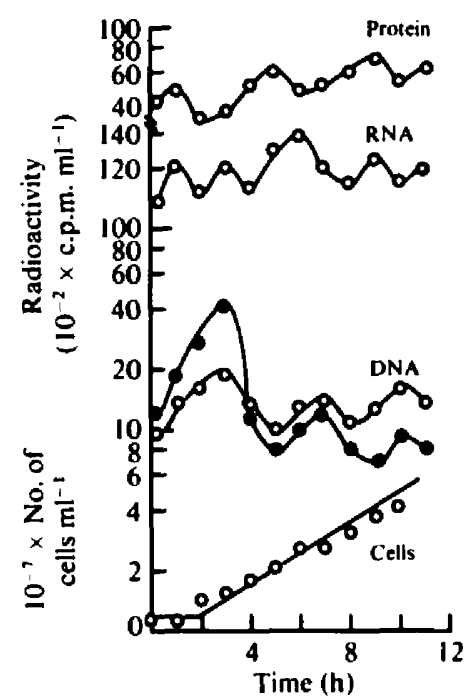

Fig. 3

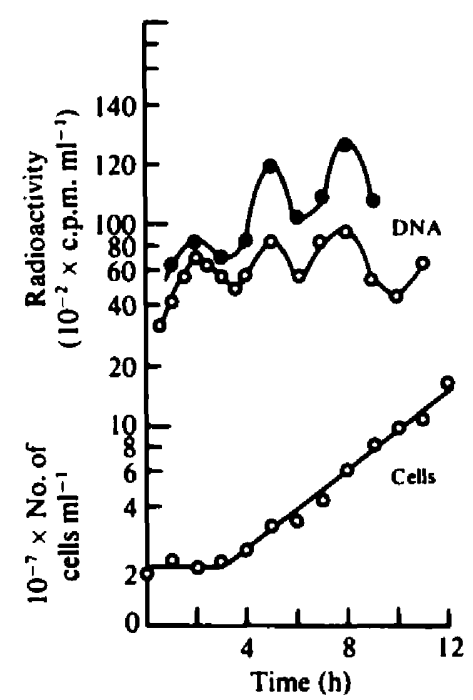

Fig. 4

Fig. 3. Rates of macromolecular synthesis by Anacystis nidulans grown under high light intensity $\left(4.8 \mathrm{~J} \mathrm{~m}^{-2} \mathrm{~s}^{-1}\right)$ at $32^{\circ} \mathrm{C}$. An exponential culture was treated as in Fig. I to induce cell synchrony. Pulselabelling and measurements of macromolecules were performed as previously (Asato, 1979). $\mathrm{H}_{3}{ }^{32} \mathrm{PO}_{4}$ was used to label RNA and DNA. The filled symbols show a repeated experiment in DNA synthesis. $\left[{ }^{3} \mathrm{H}\right.$ ]Valine served as precursor for protein systhesis. Cell counting was done in a Petroff-Hausser counter. Doubling time was $4 \mathrm{~h}$.

Fig 4. Rates of DNA synthesis in Anacystis nidulans cultures grown under high light intensity $\left(4.8 \mathrm{~J} \mathrm{~m}^{-2} \mathrm{~s}^{-1}\right.$ ) at $35^{\circ} \mathrm{C}$. DNA synthesis and cell counting methods were as described elsewhere (Asato. 1979). The filled circles show DNA synthesis measured in an independent experiment. The doubling time was $3 \mathrm{~h}$.

operons. Preliminary results in our laboratory showed increased synthesis of $23 \mathrm{~S}, 16 \mathrm{~S}, 5 \mathrm{~S}$ and $4 \mathrm{~S}$ RNA during the RNA synthesis period of a synchronized culture. The apparent lack of precise timing in the appearance of macromolecular synthesis periods particularly during the initial growth period might be explained as follows. The initiators could be activated by metabolites that act as effectors. Such a model, for example the co-ordinate regulation of DNA replication and the initiation of cell septum formation in Escherichia coli, has been proposed by Zusman $e t$ al. (1972). According to this model, the initiation of macromolecular synthesis requires the presence of an initiator which is under genetic control and a specific effector which is under metabolic control. Assuming that a similar control mechanism exists in Anacystis, effective quantities of initiator and effector may not be always formed and found precisely on schedule, particularly during the transition between dark and light incubation ( $0-4 \mathrm{~h}$ in Fig. 3). The metabolites, for example, could occur sooner or later depending on the growth conditions or they could have been made before the shift from dark to light growth. Nevertheless, an orderly sequence in the macromolecular synthesis periods occurs eventually.

Periodicity in the rates of DNA synthesis was also obtained for cultures grown under high light intensity at $35^{\circ} \mathrm{C}$ (Fig. 4). A repeated experiment showed higher rates of DNA synthesis (Fig. 4). The peaks in DNA synthesis occurred at $3 \mathrm{~h}$ intervals consistent with a $3 \mathrm{~h}$ doubling time.

The data clearly showed that the growth at high light intensities cannot simply be characterized as exponential. At $32^{\circ} \mathrm{C}$ under high light intensity, the protein, RNA and DNA synthesis periods occurred in a temporal and sequential order within a $4 \mathrm{~h}$ cell cycle rather than an $8 \mathrm{~h}$ cell cycle. These observations suggest that the growth shown in Fig. 3, in fact, is essentially synchronized. 


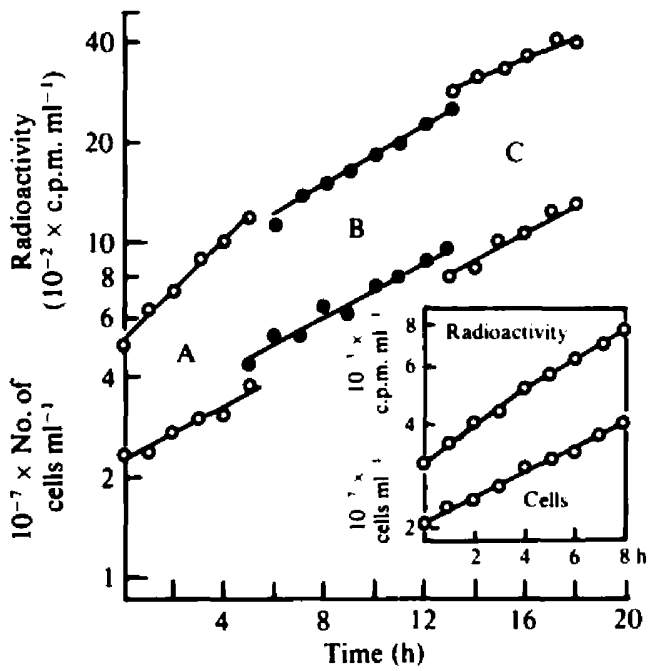

Fig. 5. Uptake of $\mathrm{N}$-acetyl[ ${ }^{3} \mathrm{H}$ lglucosamine by an exponential culture of Anacystis nidulans. Cells were grown at $32^{\circ} \mathrm{C}$ under moderate light intensity $\left(3 \cdot 2 \mathrm{~J} \mathrm{~m}^{-2} \mathrm{~s}^{-1}\right) . N$-Acety][ $\left.{ }^{3} \mathrm{H}\right]$ glucosamine was added $4 \mathrm{~h}$ before sampling. Plots $A, B$ and $C$ represent three different sets of experiments. The inset shows the uptake of labelled cell wall precursor for a culture grown under high light intensity $\left(4.8 \mathrm{~J} \mathrm{~m}^{-2} \mathrm{~s}^{-1}\right)$ at $32{ }^{\circ} \mathrm{C}$. The doubling time under these conditions was $4 \mathrm{~h}$.

\section{Patterns of cell wall synthesis}

It seemed that the pattern of cell wall synthesis might shed light on the differences in the growth characteristics mentioned above. In the first series of experiments, cell wall synthesis was followed by measuring the uptake of $\mathrm{N}$-acetyl[ $\left.{ }^{3} \mathrm{H}\right]$ glucosamine in cultures growing exponentially at $32^{\circ} \mathrm{C}$ under moderate light intensity (Fig. 5). At a cell concentration of about 2$4 \times 10^{7}$ cells $\mathrm{ml}^{-1}$, the rate of uptake of cell wall precursors doubled in $4 \mathrm{~h}$ rather than in $8 \mathrm{~h}$. From approximately $4 \times 10^{7}$ to $8 \times 10^{7} \mathrm{cells} \mathrm{ml}^{-1}$, the rate of uptake of cell wall precursors was proportional to the growth rate. Beyond $8 \times 10^{7}$ cells $\mathrm{ml}^{-1}$, the rate of uptake decreased noticeably. These changes did not always occur at these cell concentrations in repeated experiments (data not shown). In general, the changes in rates were in some manner associated with the increase in cell density. Changes in the rates of uptake of labelled $\mathrm{N}$-acetylglucosamine were also observed (although less dramatically) when the exponential cultures were grown at high light intensity (see inset in Fig. 5). In Fig. 6, average cell lengths are shown at hourly intervals from the 7 th to the 19 th hour for a synchronized culture grown at $32{ }^{\circ} \mathrm{C}$ under moderate light intensity. After the first cell division period, the highest average cell length was $7 \cdot 2 \mu \mathrm{m}$, while after the second division period it was $5 \cdot 2 \mu \mathrm{m}$. The reduction in the average cell length occurred as the cell density increased from approximately $3 \times 10^{7}$ to $6 \times 10^{7}$ cells $\mathrm{ml}^{-1}$. Thus, the changes in the rates of uptake of cell wall precursors were more correctly attributable to changes in cell size (cell volume).

In the second series of experiments the rate of uptake of $\mathrm{N}$-acetyl $\left[{ }^{3} \mathrm{H}\right]$ glucosamine was determined by pulse-labelling. The most notable feature found was the periodic synthesis of cell wall material. There were five peaks during the cell cycle, although the shoulder after $10 \mathrm{~h}$ incubation may represent the presence of an additional unresolved peak. A further experiment did show an additional peak at $10.5 \mathrm{~h}$ (data not shown). Three peaks associated with the cell division period $(11-15 \mathrm{~h})$ may represent the formation of the cell septum. Cell wall synthesis appeared, therefore, to occur throughout the cell cycle in short pulsating modes. This pattern may explain why the cells did not halve in length immediately after septum formation. It was also found that the peak synthesis rates did not always double when the cell number doubled. The absence of doubling in the synthesis rates within the generation time most probably resulted from a decrease in cell size as cell density increased to a certain level, as noted here and by Asato (1979). 


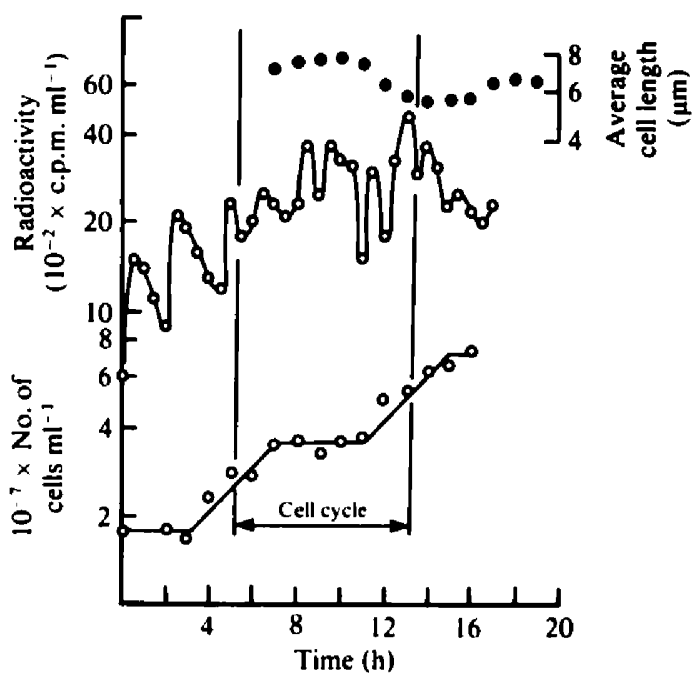

Fig. 6. Pulse-labelling with $\mathrm{N}$-acetyl[ ${ }^{3} \mathrm{H}$ gglucosamine of synchronized Anacystis nidulans grown at $32^{\circ} \mathrm{C}$ under moderate light intensity $\left(3 \cdot 2 \mathrm{~J} \mathrm{~m}^{-2} \mathrm{~s}^{-1}\right)$. Uptake of the radioactive cell wall precursor was permitted for $30 \mathrm{~min}$. For the average cell length measurements, $5 \mathrm{ml}$ of culture was treated with one drop of formalin to inactivate the cells. The sample was centrifuged at 8000 r.p.m. for 2 min and the supernatant was discarded. The cells were resuspended by mixing in the residual medium which remained in the centrifuge tube. A loopful of cells was smeared on a glass slide and stained with methylene blue. One hundred cells were measured per sample with a calibrated ocular micrometer under a light microscope.

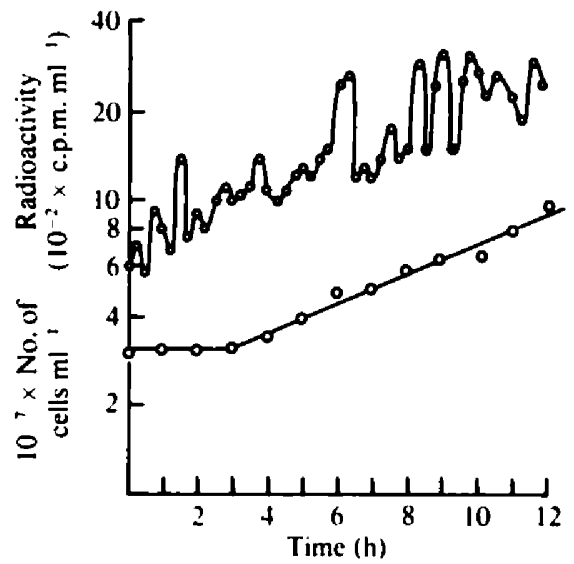

Fig. 7. Pulse-labelling of synchronized Anacystis nidulans with $\mathrm{N}$-acetyl[ $\left.{ }^{3} \mathrm{H}\right] \mathrm{glucosamine}$ at $32 \mathrm{C}$ under high light intensity $\left(4.8 \mathrm{~J} \mathrm{~m}^{-2} \mathrm{~s}^{-1}\right)$. Culture conditions were the same as in Fig. $3 . N$ Acetyl[ $\left.{ }^{3} \mathrm{H}\right] g$ lucosamine was added for $15 \mathrm{~min}$. The doubling time was $4 \mathrm{~h}$.

Would the same pattern of cell wall synthesis occur when the synchronized culture was grown at $32{ }^{\circ} \mathrm{C}$ but under high light intensity? Fig. 7 shows similar patterns of cell wall synthesis except that nine peaks occurred within the $8 \mathrm{~h}$ period from $3 \mathrm{~h}$ to $11 \mathrm{~h}$. Because cell number increased exponentially, it was difficult to determine which of the peaks were associated with cell septum formation. It is possible that the synthesis of the cell septum overlapped to some extent the periods of synthesis of the peripheral cell wall. Cell wall synthesis under high light intensity occurred in an ordered pattern similar to the pattern found in the synchronized cultures described above, although the synthesis periods appeared in a pattern consistent with a $4 \mathrm{~h}$ rather than an $8 \mathrm{~h}$ cell cycle. 


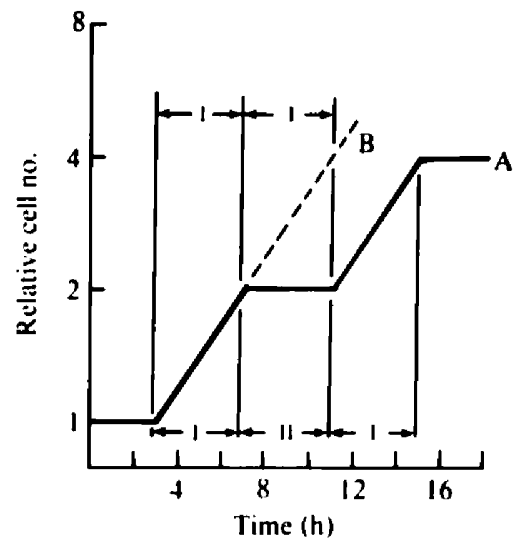

Fig. 8. Possible growth model for synchronized Anacystis nidulans at high light intensity $\left(4.8 \mathrm{~J} \mathrm{~m}^{-2} \mathrm{~s}^{-1}\right)$. Plot A depicts a typical step-wise growth pattern for a synchronized culture grown under moderate light intensity $\left(3.2 \mathrm{~J} \mathrm{~m}^{-2} \mathrm{~s}^{-1}\right)$ at $32 \mathrm{C}$. (I) indicates the cell division period: (II) indicates the period of the cell cycle when the cell septum formation does not occur. Plot B shows the slope of the line of one cell division period, including the slope (dashed lines) of the next cell division period. The combined periods of cell divisions (minus the period when the cell septum is not made) generates a slope consistent with a doubling time of $4 \mathrm{~h}$. The model suggests that a new round of cell septum formation starts as the previous round is being completed in synchronized cultures grown under high light intensity. Further implications of the model are discussed in the text.

\section{Concluding remarks}

A state of balanced growth was not achieved for synchronized cultures grown under high light intensity, i.e. the rates of macromolecular synthesis analysed did not double from one generation to the next as observed for heterotrophic bacteria (Maaloe \& Kjeldgaard, 1966). Growth, however, can be described in terms of cell size. As cell density increases, cell size decreases. The macromolecular contents per cell should decrease proportionately although the cell number continues to increase. The changes in the rates of macromolecular synthesis from one generation to the next could depend on cell volume during the periods when cell number increases exponentially. The quantities of macromolecules synthesized in a cell are probably regulated by feed-back loops, i.e. the amounts of specific macromolecules synthesized could be associated in some way with the amounts of macromolecules present per unit volume of the cell (Asato, 1983). A more or less than doubling in the peaks of specific macromolecular synthesis rates and the extended period of synthesis from one generation to the next observed in this and other studies (Asato, 1979, 1983) are apparently associated with cell size. It should be noted that cell wall synthesis occurred in bursts, indicating a relationship between macromolecular synthesis and cell volume increase. It is not yet known whether the increase in cell volume was a response to an increase in macromolecules synthesized or vice versa. In any case, there appears to be a close coordination of cell wall synthesis and other macromolecules synthesized during the incubation period where cell number doubled.

The reasons why cell numbers increased exponentially and growth rates doubled for all growth temperatures and time periods studied obviously require further detailed investigation. However, one explanation may be as follows: peripheral cell wall and septum formation are regulated in a temporal order, as are other cell cycle events. However, cell septum formation appears to be temperature dependent and does not increase as the light intensity is increased, as indicated in this study. For a synchronized culture grown at $32^{\circ} \mathrm{C}$ under moderate light intensity, the cell division period is $4 \mathrm{~h}$. At high light intensity, the initiation of cell septum formation occurs on schedule every $4 \mathrm{~h}$. As the period of one cell septum formation is being completed a new period of cell septum formation starts and is completed within the next $4 \mathrm{~h}$ period (Fig. 8). Consequently, cell septum formation occurs continuously and as a result the cell number increases continuously. The protein. RNA, DNA and peripheral cell wall synthesis 
periods could be co-ordinated to occur in a temporal order within the period of cell septum formation in cells containing multiple genomes. Based on the genome size of Anacystis estimated by renaturation kinetics (Herdman \& Carr, 1974), quantitative data (Asato \& Folsome, 1970; Asato, 1983) indicated that there may be more than two genomes per cell. This pattern of cell growth is applicable only to the conditions used here. Evidently, at higher light intensity and in medium supplemented with $5 \% \mathrm{CO}_{2}$, the rates of cell septum formation can be increased (Mann \& Carr, 1974).

The growth characteristics at the molecular level indicate the remarkable ability of $A$. nidulans (and perhaps other related obligate phototrophs) to take advantage of the changing environmental conditions in nature. These organisms do not grow in the dark. The advantage of not growing normally in the dark is unclear, although this feature is retained by higher plants. When light becomes available Anacystis cells immediately reinitiate the cell cycle. Growth rates can be significantly increased as the light intensity and temperature are elevated such that cell number or mass, or both, can be rapidly generated. This feature could in part be responsible for the rapid growth of these organisms as water blooms. While the results of these and other studies on the cell cycle of Anacystis offer further understanding of the life of these cyanobacteria in the natural environment, the data presented here may also serve as an important guide in evaluating cell cycles that are analysed in controlled laboratory environments.

\section{REFERENCES}

Asıto. Y. (1979). Macromolecular synthesis in synchronized cultures of Anacystis nidulans. Journal of Bacteriology 140, 65-72.

As^To, Y. (1983). Dark incubation causes reinitiation of cell cycle events in Anacystis nidulans. Journal of Bacteriology 153, 1315-1321.

Asato, Y. \& Folsome, C. E. (1970). Temporal genetic mapping of the blue-green alga. Anacystis nidulans. Genetics 65, 407-419.

Herdman, M. \& Carr, N. G. (1974). Estimation of the genome size of the blue-green algae from renaturation rates. Archices of Microbiology. 99, 251- 254.
MaAloe, O. \& KJeldgard, N. O. (1966). Control of Macromolecular Synthesis. New York: W. A. Benjamin.

MANN, N. \& CARR, N. G. (1974). Control of macromolecular composition and cell division in the blue-green alga Anacystis nidulans. Journal of General Microbiology 83, 399-405.

Zusman. D. R.. Inouye, M. \& Pardee, A. B. (1972). Cell division in Escherichia coli: evidence for regulation of septation by effector molecule. Journal of Molecular Biology 69. 119-136. 